\title{
THE RUSSIAN REVOLUTION
}

\section{7-1967}

What has been achieved in the fifty years of Soviet rule in Russia?

The October 1967 issue of

\section{SURVEY}

continues the assessment contained in the July issue, and carries a number of important articles by eminent scholars answering this question in regard to literature, strategy, agriculture, labour and education, foreign policy, military doctrine, administration.

\section{SURVEY}

is published quarterly.

Annual subscription $£ 2$ or $\$ 6.00$.

Free specimen copy on request from

Survey,

Ilford House,

133 Oxford Street,

London W.1. 


\title{
INTERNATIONAL STUDIES
}

\author{
QUARTERLY JOURNAL \\ OF THE INDIAN SCHOOL OF INTERNATIONAL STUdiES, \\ Sapru House, Barakhamba Road, New Delhi 1 \\ (INDIA)
}

Vol. 9, No. 2, October 1967

CONTENTS

Guerrilla Warfare and International Law Rhamatullah Khan

Sectoral Allocation in the Plans of Pakistan

K. L. Seth

Notes AND Memoranda

Seminar on Nuclear Weapons and Foreign Policy

M. L. Sondhi

Afghanistan during Amanullah's Reign: 1919-1929

Amalendu Guha

\section{BIBLIOGRAPHY}

India and World Affairs: An Annual Bibliography, 1966

S. Ansari, L. C. Kumar, R. P. Wasan, and Dalip Singh

\section{BoOK Reviews}

Annual Subscription: Rs 40.00; $\$ 9.00 ; 72 \mathrm{~s}$

Single copy:

Rs 10.00; $\$ 2.25 ; 18 s$

ASIA PUBLISHING hOUSE

BOMBAY - LONDON - NEW YORK 


\section{EUROPA-ARCHIV}

Zeitschrift für internationale Politik

Begründet von Wilhelm Cornides

EUROPA-ARCHIV, now in its 21st year of publication, contains articles and documents on international relations, a current chronology of world events, and a monthly bibliography of recent publications in the field of international relations.

\section{Articles in recent issues:}

James R. Schlesinger Die Verbreitung von Kernwaffen. Möglichkeiten und Grenzen der Eindämmung der Proliferation

Arnold Hottinger Die Araber nach dem dritten israelisch-arabischen Krieg

J. F. Brown Die ungarische Aussenpolitik in Schatten des Bündnisses mit der Sowjetunion

Geors ron Ranch und Die deutsch-sowjetischen Beziehungen 1917 bis 1967

Boris Meissner

Fritz Ermarth

Die militärpolitische Diskussion in der Sowjetunion unter Breshnjew und Kossygin

Willy Linder

Nassers wirtschaftliche Bankrottpolitik

Specimen copies on request

Annual subscription (24 issues): DM 65, plus postage

EUROPA-ARCHIV, VERTRIEB

6 Frankfurt, Postfach 3685

\section{ESTUDIOS INTERNACIONALES}

\section{Revista Trimestral del Instituto de Estudios Internacionales de la Universidad de Chile}

En el Vólumen I-Número 3-Octubre 1967, aparecerán entre otros los siguientes artículos:

Gabriel Valdes

ARTURO FrondIZI

Clodomiro Almeyda

Antonio Garcia

W. F. WERTHEIM

Criticas de Libros

DOCUMENTOS
Dos enfoques sobre la Integración Latinoamericana

OLAS y la crisis política en América Latina

Proceso y frustración de las Reformas Agrarias en América Latina

Indonesia antes y después del Golpe de Untung

Precio: U.S.\$1.50 por ejemplar, franqueo incluído; $\$ 6.00$ anual

DiRIGIRSE A: Departamento de Subscripciones, Estudios Internacionales, Casilla 14187, Correo 15, Santiago de Chile 


\section{MINERVA}

A REVIEW OF SCIENCE, LEARNING AND POLICY

Editor: EDWARD SHILS

VOLume V, Number 4

SUMMER, 1967

ARTICLES

The International Circulation of Human Capital Brinley Thomas

Scientific Policy in the Netherlands

H. W. Julius

British Universities and the Public Purse

Max Beloff

The Growth of Science in Society

Michael Polanyi

REPORTS AND DOCUMENTS

The Efficiency of Science in the Soviet Union Academician V. Trapeznikov

Address by the Vice-Chancellor, Dr. K. O. Dike,

to Congregation of the University of Ibadan

Draft Recommendations of the Conference on the

Role of the University College, Dar es Salaam, in a Socialist Tanzania

CORRESPONDENCE

CHRONICLE

\section{MINERVA}

Ilford House, 133-135 Oxford Street, London, W.1

Please send me the current issue MINERVA

$\mathrm{CQ} / 20$

I wish to subscribe to MINERVA (delete as necessary)

Single copy $7 \mathrm{~s}$. 6d./\$1.25. Annual subscription 30 s. $/ \$ 5$

Name

Address

Minerva, Ilford House, 133-135 Oxford Street, London, W.1 
China Under Mao: Politics Takes Command

Selections from The China

Quarterly edited by

Roderick MacFarquhar

Eminent Sinologists from many

different quarters discuss the

newly emerging China-in a

collection of articles originally

published in The China

Quarterly. The changing internal

structure, foreign policy, military

affairs, the economy and

industrialization, agriculture

and the communes, education,

art and science are major topics.

$\$ 10.0080 /$-hardcover,

$\$ 3.9520 /$ - paper

The Party and the National

Question in China

edited and translated by

George Moseiey

Chang Chih-i, formerly Deputy

Director of the United Front Work

Department of the Chinese

Communist Party, discusses the

40-million-strong minority

population in China-and the

problems it creates in a

"classless" society.

$\$ 7.5060 \%$ -
Sino-Soviet Relations and

Arms Control

edited by Morton H. Halperin

Distinguished contributors

comment on the Sino-Soviet

dispute in its relation to the

arms control issue, seeking to

illuminate the security problems facing the West and to examine the prospects for arms control agreements as they are affected by conflict within the Communist world. $\$ 10.0080 /$ -
The Sino-Soviet Rift by William E. Griffith

A chronological summary, . analysis, and documentation of developments in the Sino-Soviet dispute between February 1962 and November 1963-including a brief history of the dispute, notes on the influence of events in Cuba and India, and an account of Communist Party developments through the signing of the 1963 Test Ban Treaty. $\$ 7.95$ 64/-hardcover, $\$ 2.95$ 15/-paper

Sino-Soviet Relations, 1964-1965 by William E. Griffith A continuation volume to William E. Griffith's The Sino-Soviet Rift, this is a discussion of more recent developments in the Sino-Soviet dispute, including the key documents pertinent to the controversy. $\$ 10.0080 /$-hardcover, $\$ 3.95$ 20/-paper

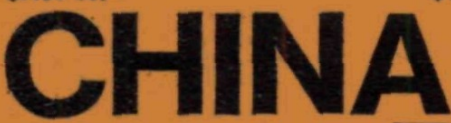

At your bookstore, or order from Book Centre Limited, North Circular Rọd, Neasden, London NW 10
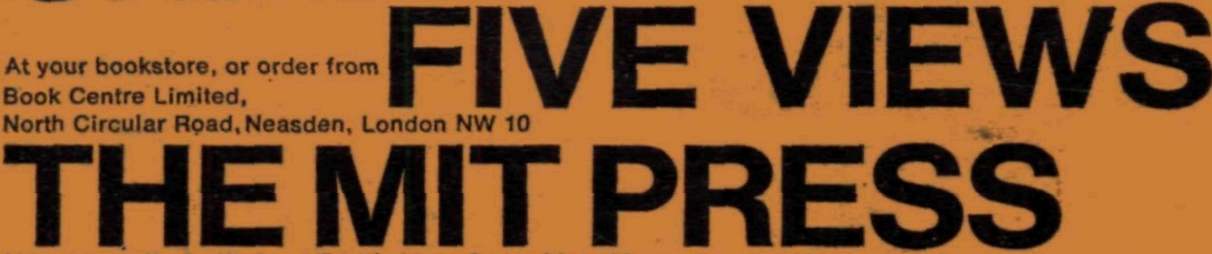